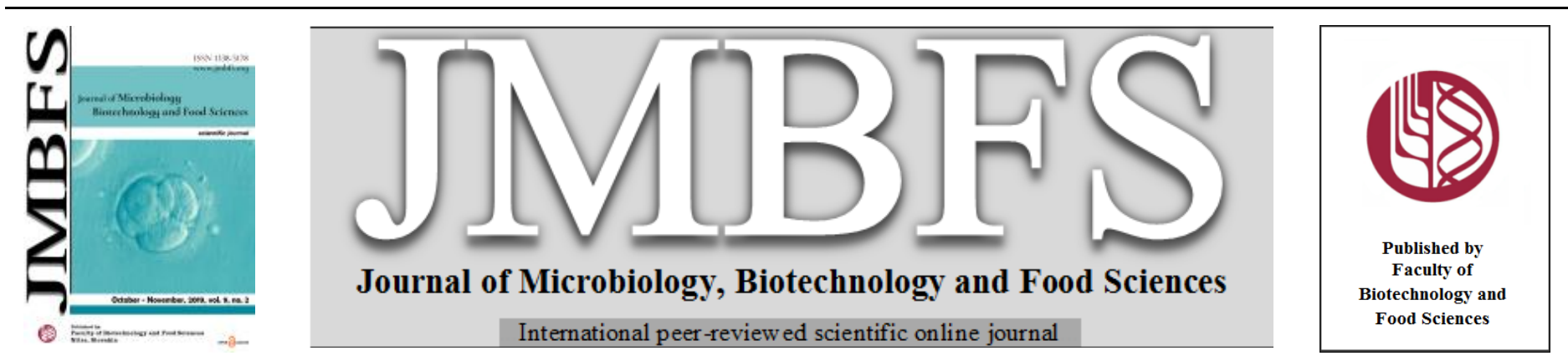

\title{
EFFECT OF GERMINATION ON FREE RADICAL SCAVENGING ACTIVITIES AND ANGIOTENSIN I-CONVERTING ENZYME INHIBITORY OF MELINJO (Gnetum gnemon L) SEED PROTEINS
}

\author{
Erni Noviyanti ${ }^{1,2}$, Anang Supriyadi ${ }^{1}$, Laras Sekar Arum ${ }^{1}$, Rida R. Akbar ${ }^{1}$, Tri Agus Siswoyo ${ }^{1,2 *}$ \\ Address(es): \\ ${ }^{1}$ Graduate School of Biotechnology and Center of Excellence on Crop Industrial Biotechnology, University of Jember, Jln Kalimantan 37, Jember 68121, Indonesia. \\ ${ }^{2}$ Department of Agronomy, Faculty of Agriculture University of Jember, Jln Kalimantan III/23, Jember 68121, Indonesia.
}

*Corresponding author: triagus.faperta@unej.ac.id

doi: 10.15414/jmbfs.2020.9.4.809-812

\section{ARTICLE INFO}

Received 17. 1. 2019

Revised 25. 9. 2019

Accepted 27. 9. 2019

Published 3. 2. 2020

Regular article

OPEN $\partial_{\text {AcCESS }}$

\begin{abstract}
The effect of germination on free radical scavenging activities and Angiotensin I-Converting Enzyme (ACE-I) inhibitory of melinjo (Gnetum gnemon) seed proteins was studied to determine its potential use as a nutraceutical ingredient. Investigations into the protein profiles, amino acid composition, free radical scavenging activities and ACE-I-inhibitory of proteins extracted from melinjo seed during germination ( 0 to 21 days) were carried out. The concentration of amino acids detected in the melinjo seed samples ranged from 0.30 to $12.75 \mathrm{~g} / 100 \mathrm{~g}$ protein and the degree of hydrolysis during germination at $21^{\text {st }}$ days was significantly highest than that of either $(0-14$ days). Furthermore, with all samples a large small-sized peptides degree ( $<10 \mathrm{kDa})$ was observed with an increasing degree of hydrolysis value. The free radical scavenging activities were measured using different standard methods, and ACE-I inhibitory activity was determined using in vitro ACE-I inhibitory assay. The time of germination showed a significant effect $(p<0.05)$ on free radical scavenging $\left(\mathrm{ABTS}^{2+}, \mathrm{DPPH}, \mathrm{O}_{2}{ }^{\circ}\right.$ and $\left.\mathrm{OH}^{\circ}\right)$ activities and ACE-I inhibitory. The above results indicated that germination time has positively affected ACE-I inhibitory activity and free radical scavenging activities.
\end{abstract}

Keywords: Melinjo, Protein, Radical Scavenging, ACE-inhibitory, Gnetum gnemon, Germination

\section{INTRODUCTION}

Bioactive compounds were found in seeds and are known as functional compounds that provide physiological effects, and that can help maintain human health. Some biochemical processes such as germination are considered both simple and economical to improve the nutritive value of seeds by causing desirable changes in the nutrient availability and texture characteristics (Fernandez et al., 2009). An extensive breakdown of seed-storage compounds and the synthesis of structural proteins and other cell components take place during the germination. Primary and secondary compounds, many of which are considered beneficial as antioxidants, often change dramatically during the germination. The germination process can make significant changes in the biochemical properties of the seeds due to the activation of enzymatic processes that convert storage macromolecules into nutrients for seed growth. Sefatie et al., (2013) reported that the germination process has the potency to produce bioactive peptides directly as a product of the hydrolysis of storage proteins by endogenous proteases in seeds. The protein hydrolyzed is the product of the hydrolysis reaction or the breaking of the peptide bonds in the protein molecule containing a mixture of components of various peptides and free amino acids depending on the degree of hydrolysis, the velocity and degree of hydrolysis by an enzyme influenced by the substrate concentration, enzyme concentration, $\mathrm{pH}$ and temperature (Ramakrishna \& Ramakrishna, 2006). Duangmal \& Sangsukiam (2015), identified and refined small molecular weight peptides $(0.5$ to $3 \mathrm{kDa}$ ) produced at various germination phases of mung beans (Vigna radiata (L) Wilczek, sonali b1) by chromatography and ultrafiltration methods. Some researchers had reported the ability of germinated seeds to produce bioactive peptides. Mamilla \& Mishra (2017) have proved that germination of lentils (Lens culinaris Medik cv. Gachsaran) was able to generate bioactive peptide directly and obtained ACE inhibitory peptide extract with activity as much as $84.3 \%$.

Melinjo tree (Gnetum gnemon L.) has many benefits because almost all parts of the plant can be utilized as in seed melinjo which can be used as the basic ingredients of making crackers (emping). Indonesian people are generally more familiar with melinjo especially melinjo seeds as vegetables. Melinjo is one of the seeds that have a high protein content of $16-19 \%, 58 \%$ of starch, $16.4 \%$ of lipid and $1 \%$ of phenolic. Melinjo seed was found two protein major that have activity antioxidants that effectively counteract free radicals (Siswoyo et al.,
2011). From the potential of melinjo seed protein, yet no further information about protein or peptide ACE-I inhibitor and antioxidant activities during germination of melinjo seeds. Therefore, the experiment was designed to see the effect of germination on the level of ACE-I inhibitor and radical scavenging activities, so that most active stage of the seed is identified for the maximum potential of ACE-I inhibitor and free radical scavenging properties. Furthermore, ACE-I inhibitor and scavenging proteins can be used as a nutraceutical compound.

\section{MATERIAL AND METHODS}

\section{Samples and Germination Process}

Germination was carried out following the procedure of Kiran et al. (1991) Melinjo seeds were treated to warm stratification to stimulate and accelerate the germination of the seed, the seed skins were discarded, and then the seeds were sterilized with $70 \%$ ethanol then washed with aquadest. After drying for $2 \mathrm{~h}$, the seeds were wrapped with a damp cloth filled with chaff and incubated for 3 weeks at $40^{\circ} \mathrm{C}$. Every 3 days a once the seeds were sprayed using distilled water during the germination period. Seeds were harvested at 0 (ungerminated), $3^{\text {rd }}, 7^{\text {rd }}$ $14^{\text {th }}$ and $21^{\text {st }}$ germination days (Figure 1 ). Germinated seeds were frozen at $-20^{\circ} \mathrm{C}$ for $12 \mathrm{~h}$ to stop the germination.

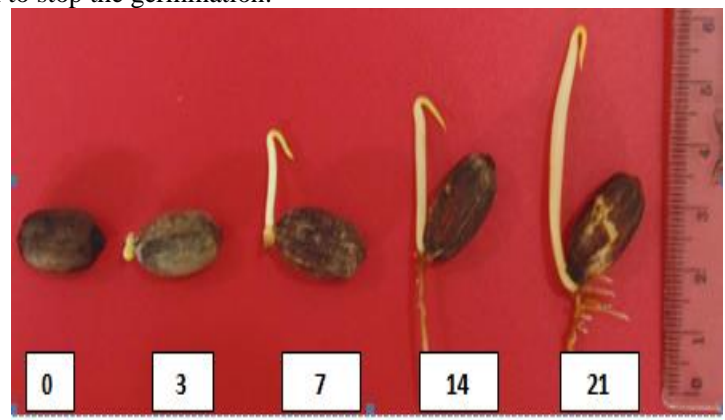

Figure 1 Gnetum gnemon seed during germination (days) 


\section{Extraction sample}

Protein extraction of melinjo seed was done by grounding and homogenized $1 \mathrm{~g}$ of fresh seed with Tris- $\mathrm{HCl}$ buffer $(3 \mathrm{~mL}, 50 \mathrm{mM}, \mathrm{pH}$ 6.8) then centrifuged $10.000 \mathrm{rpm}$ for $15 \mathrm{~min}$, and the supernatant was stored at liquid nitrogen. The supernatant was analyzed for total protein content using the Bradford method (Bonjoch \&Tamayo, 2001). As much as $5 \mu \mathrm{L}$ of seed extracts solution were added with $45 \mu \mathrm{L}$ aquadest and then introduced with $950 \mu \mathrm{L}$ of Bradford solution. Absorbance was measured at a wavelength of $595 \mathrm{~nm}$, and the result was compared with bovine serum albumin (BSA) standard to determine the dissolved protein content.

\section{Degree of Hydrolysis}

The determination of degree of hydrolysis (DH) values were using trinitrobenzenesulphonic acid (TNBS) reaction (Alder-Nissen, 1979), and the measurement was adapted from Thiansilakul et al. (2007). The amount of $\alpha$ amino acids were determined in the sample of the original of the protein extract after acid hydrolysis with $6 \mathrm{M} \mathrm{HCl}\left(100^{\circ} \mathrm{C}, 24 \mathrm{~h}\right)$ and soluble $\alpha$-amino acid estimated in the hydrolytic solution at the beginning and the end of the reaction. As much as $125 \mu \mathrm{L}$ of protein seed extract solution was mixed with phosphate buffer $(2.0 \mathrm{~mL}, 200 \mathrm{mM}, \mathrm{pH} 8.2)$ and TNBS solution $(1.0 \mathrm{~mL}, 0.1 \%)$ and was incubated $\left(50^{\circ} \mathrm{C}, 30 \mathrm{~min}\right)$ in a water bath. The reaction was stopped by adding $\mathrm{Na}_{2} \mathrm{SO}_{3}(2.0 \mathrm{~mL}, 0.1 \mathrm{M})$ followed by cooling to room temperature for $15 \mathrm{~min}$. Absorbance was quantified using a spectrophotometer at a wavelength of 420 $\mathrm{nm}$, and the results were compared with L-leucine standard to quantification the dissolved $\alpha$-amino acid. The degree of hydrolysis was calculated as follows: Degree of hydrolysis $(\%)=[($ At-Ao $) / A m a x-A o)] \times 100$, where At is the amount of $\alpha$-amino acid released at time $t$; Ao is the amount of free amino acid in the original protein extract; Amax is total amino acid in the original protein extract obtained after acid hydrolysis.

\section{Gel Electrophoresis}

Analysis of protein pattern was done by denaturing gel electrophoresis (SDSPAGE) method performed according to the Laemmli method (1970). A total of $10 \mu \mathrm{g}$ protein samples taken from the extracted sample plus $10 \mu \mathrm{L}$ buffer loading (95\% buffer loading plus 5\% $\beta$-mercaptoethanol) were denatured in boiling water for $3 \mathrm{~min}$. The prepared protein samples were then loaded into gel well and electrophoresed for 2 to $4 \mathrm{~h}$. $10 \mu \mathrm{L}$ of markers were also added to simplify marking of sample protein molecular weight. After removal from the plate sequence, the protein band staining was performed by immersing the electrophoresis gel in a $10 \%$ Coomassie brilliant blue solution for $24 \mathrm{~h}$. The excess color was then removed by soaking the gel in destaining solution $(50 \mathrm{~mL}$ of aquadest, $40 \mathrm{~mL}$ of methanol, $10 \mathrm{~mL}$ of glacial acetic acid) until the ge becomes clear forming revealing clear bands parted from each other. The bands on the electrophoresis gel were documented.

\section{Determination of Amino Acid}

Amino acid hydrolysis was carried out by weighing $0.1 \mathrm{~g}$ each of the five samples and added $5 \mathrm{~mL}$ of $6 \mathrm{~N} \mathrm{HCl}$. The hydrolysis process is carried out at $110^{\circ} \mathrm{C}$ for $22 \mathrm{~h}$. After the hydrolysis, the mixture was cooled at room temperature then transferred to a $50 \mathrm{~mL}$ measuring flask with aquabidest added up to boundary marker and then filtered using a $0.45 \mu \mathrm{m}$ filter. It was then added with $0.4 \mathrm{~mL} 50 \mathrm{mM}$ alpha aminobutyric acid (AABA) as an internal testing standard. As much as $20 \mu \mathrm{L}$ of hydrolysate was injected into the UPLC system (Waters 2475, US) by using AccQ. Tag Ultra C18 $\mu \mathrm{m}(2.1 \times 100 \mathrm{~mm})$ column with Photodiode Array (PDA) as a detector at $260 \mathrm{~nm}$ to identify the amino acid compositions.

\section{Determination of ACE-I Inhibitory Activity}

The sample $(10 \mathrm{mg} / 1 \mathrm{~mL})$ was dissolved in demineralized water and analyzed by an ACE-I inhibition assay. The ACE-I inhibitory activity was measured in-vitro as described by Li et al. (2005). For each test, $20 \mu \mathrm{L}$ of sample solution of ACEI Inhibitor with $50 \mu \mathrm{L}$ of $5 \mathrm{mM}$ Hippuryl-His-Leu (HHL) in sodium borate buffer $\left(100 \mathrm{mM}\right.$, pH 8,3) containing $300 \mathrm{mM} \mathrm{NaCl}$ was pre-incubated at $37^{\circ} \mathrm{C}$ for $5 \mathrm{~min}$. The reaction was started by the addition of ACE solution $(10 \mu \mathrm{L}, 100$ $\mathrm{mU} / \mathrm{mL}$ ), and was incubated at same temperature for $30 \mathrm{~min}$. The reaction was terminated by the addition of $\mathrm{HCl}(100 \mu \mathrm{L}, 1 \mathrm{M})$ and then added of sodium borate buffer to a volume of $0.5 \mathrm{~mL}$. Hippuric acid (HA) released from HHL by ACE-I was observed by addition of quinoline and benzene sulfonyl chloride Finally, the absorbance was quantified by spectrophotometer at wavelength of $228 \mathrm{~nm}$ and the results were compared with HA standard. The results are displayed as a mean of triplicate measurements. The $\mathrm{IC}_{50}$ value was defined as the peptide concentration that inhibits the $50 \%$ of ACE-I activity.

\section{2,2-diphenyl-1-picrylhydrazyl (DPPH) Radical Scavenging Ability}

DPPH antioxidant activity was carried out according to the method proposed by Galvez et al. (2005). About $0.5 \mathrm{mM}$ DPPH solution was dissolved in methanol A volume of $100 \mu \mathrm{L}$ supernatant obtained from the sample extract was taken and then added $100 \mu \mathrm{L}$ methanol and $800 \mu \mathrm{L}$ of $50 \mathrm{mM}$ DPPH. The solution was then incubated for $20 \mathrm{~min}$ and measured its absorbance at $517 \mathrm{~nm}$ wavelength.

\section{2,2'-azino-bis (3-ethyl benzothiazole-6-sulfonic acid) (ABTS) Radical Scavenging Ability}

The antioxidant activity was assayed by $\mathrm{ABTS}^{2+}$ method Re et al. (1999). The ABTS was generated by the reaction of an ABTS aqueous solution $(7 \mathrm{mmol} / \mathrm{L})$ with potassium persulfate $(2.45 \mathrm{mmol} / \mathrm{L})$. Before the assay, ABTS was incubated in the dark for $16 \mathrm{~h}$, and the absorbance was $0.7(734 \mathrm{~nm})$. The assay contained $950 \mu \mathrm{L}$ of ABTS solution in sodium phosphate buffer saline and the protein extracts in various concentrations. The absorbance was measured at $734 \mathrm{~nm}$.

\section{Hydroxyl Radical Scavenging}

Hydroxyl radical scavenging activity was analyzed as described by Halliwell et al. (1987). As much as $150 \mu \mathrm{L}$ of protein extract was introduced with $50 \mu \mathrm{L}$ of $28 \mathrm{mM}$ 2-deoxy-D-ribose (in $20 \mathrm{mM}$ potassium phosphate buffer, $\mathrm{pH} 7.4$ ), 100 $\mu \mathrm{L}$ of $1 \mathrm{mM}$ Ethylenediaminetetraacetic acid (EDTA), $10 \mu \mathrm{L}$ of $10 \mathrm{mM}$ Ferric chloride solution $\left(\mathrm{FeCl}_{3}\right), 10 \mu \mathrm{L}$ of $1 \mathrm{mM}$ Hydrogen peroxide $\left(\mathrm{H}_{2} \mathrm{O}_{2}\right), 100 \mu \mathrm{L}$ of $1 \mathrm{mM}$ ascorbic acid and incubated at $37^{\circ} \mathrm{C}$ for $1 \mathrm{~h}$. After incubated, the solution was then added with $500 \mu \mathrm{L}$ of $1 \%$ tertiary butyl alcohol (TBA) and $500 \mu \mathrm{L}$ of $2.8 \%$ trichloroacetic acid (TCA) then reincubated for $30 \mathrm{~min}$ at a temperature of $80^{\circ} \mathrm{C}$. The absorbance was measured at $532 \mathrm{~nm}$ using a spectrophotometer.

\section{Superoxide radical scavenging}

Superoxide anion radicals were analyzed by Tang et al. (2010), $200 \mu \mathrm{L}$ sample was added into $1.7 \mathrm{~mL}$ of $50 \mathrm{mM}$ Tris- $\mathrm{HCl} \mathrm{pH} 8.2$ than incubate for $10 \mathrm{~min}$ followed by addition of $100 \mu \mathrm{L}$ of $10 \mathrm{mM}$ pyrogallol (in $10 \mathrm{mM} \mathrm{HCl}$ ). Measured slop for $4 \mathrm{~min}$ at wavelength $320 \mathrm{~nm}$.

\section{Statistical analysis}

The result was expressed as mean values and standard deviation $( \pm \mathrm{SD})$. The analysis of variance was performed using one-way analysis of variance (ANOVA) and differences between the means of samples were analyzed by Duncan's test at a significance level at $p<0.05$.

\section{RESULTS AND DISCUSSION}

In this study, the content of total protein of melinjo seeds was found about $16.8 \%$. According to Bhat \& Yahya (2014), the protein content of melinjo ranged from 16 to $19 \%$. Furthermore, the percentage value of total protein extracted can be obtained about $80-90 \%$ of the total content of protein. Protein extracted from germinated melinjo seed for different periods of the time were subjected to SDS-PAGE and analyzed degree of hydrolysis (DH). An appreciable increase in DH was observed from 0 to 21 days as shown in Figure 2B. The rate of $\mathrm{DH}$ of protein for interval time at $0,3,7,14$ and 21 days during the germination period was significantly increased from 0.01 to $25.31 \%$. Protein profiles from different periods of germination by SDS-PAGE yielded two major polypeptides bands with a molecular weight ranging from 100 to $10 \mathrm{kDa}$, the most prominent being 37 and $12 \mathrm{kDa}$ polypeptides (Figure 2A). During germination, the $37 \mathrm{kDa}$ polypeptide was degraded at $3^{\text {rd }}$ days and the gradual disappearance at $7^{\text {th }}$ days. Several new polypeptide bands formed in a range of 15 to $10 \mathrm{kDa}$ started appearing on the $7^{\text {th }}$ day and further intensified with the progress of the germination.
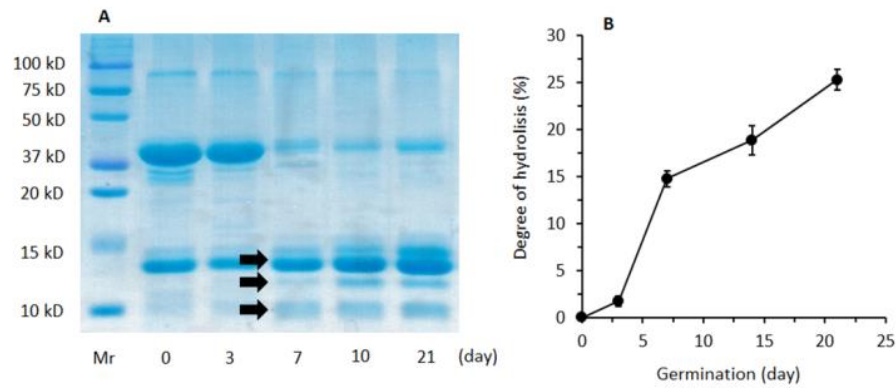

Figure 2 Effect of germination on protein profile of germinated melinjo seed. A SDS-PAGE profile of germinated melinjo seed protein; B. Degree of hydrolysis of melinjo seed protein during germination. Arrows indicate a new band which is a polypeptide fragment resulting from the germination process. 
The change in free amino acid content in the germinated melinjo seeds was shown in Table 1. The free amino acid in melinjo seed at 0 day samples, concentrations of Glu and Arg were the highest, whereas Met and Cys concentrations were relatively low. The variability in Arg Glu and Pro concentrations of the samples during the germination period was relatively very high, as exemplified by the $\mathrm{CV}=2.07,1.37$ and $1.19 \%$. Also, the concentrations of Tyr, Leu, Asp, Phe and Ser among the samples were moderately high, as shown by the CV values (in a range $0.42-0.61 \%$ )

Table 1 Amino Acid Composition (g/100 g protein) of Gnetum gnemon seeds during germination

\begin{tabular}{|c|c|c|c|c|c|c|}
\hline \multirow{2}{*}{ Amino Acid } & \multicolumn{5}{|c|}{ Germination Period (day) } & \multirow{2}{*}{ CV (\%) } \\
\hline & $\mathbf{0}$ & 3 & 7 & 14 & 21 & \\
\hline Histidine (His)* & 1.62 & 1.53 & 1.70 & 1.65 & 1.50 & 0.01 \\
\hline Threonine (Thr) & 3.66 & 2.92 & 3.08 & 2.92 & 3.18 & 0.07 \\
\hline Proline (Pro) & 5.11 & 3.35 & 2.40 & 2.22 & 2.34 & 1.19 \\
\hline Tyrosine (Tyr)* & 5.42 & 4.55 & 4.53 & 4.66 & 4.25 & 0.15 \\
\hline Leucine (Leu) & 5.90 & 4.32 & 4.91 & 4.28 & 3.98 & 0.46 \\
\hline Aspartatic Acid (Asp) & 7.15 & 5.89 & 5.49 & 5.36 & 5.15 & 0.51 \\
\hline Lysine (Lys)* & 4.15 & 4.30 & 4.44 & 4.11 & 4.24 & 0.01 \\
\hline Glycine (Gly) & 4.41 & 3.47 & 3.12 & 2.91 & 2.89 & 0.32 \\
\hline Arginine (Arg)* & 8.86 & 7.24 & 5.68 & 5.22 & 5.10 & 2.07 \\
\hline Alanine (Ala) & 4.02 & 3.54 & 3.14 & 3.21 & 3.14 & 0.11 \\
\hline Valine (Val) & 4.69 & 3.82 & 3.77 & 3.42 & 3.29 & 0.24 \\
\hline Isoleucine (lle) & 3.12 & 2.65 & 2.88 & 2.63 & 2.52 & 0.05 \\
\hline Phenylalanine (Phe) & 3.78 & 2.06 & 2.19 & 2.22 & 2.19 & 0.42 \\
\hline Glutamic Acid (Glu) & $\begin{array}{c}12.7 \\
5\end{array}$ & $\begin{array}{c}11.7 \\
4\end{array}$ & $\begin{array}{c}10.3 \\
2\end{array}$ & $\begin{array}{c}10.3 \\
1\end{array}$ & 9.48 & 1.37 \\
\hline Serine (Ser) & 5.35 & 4.86 & 3.75 & 3.49 & 3.42 & 0.61 \\
\hline Methionine (Met)* & 0.92 & 0.86 & 0.81 & 0.82 & 0.88 & 0.00 \\
\hline Cysteine (Cys)* & 0.65 & 0.44 & 0.47 & 0.40 & 0.46 & 0.01 \\
\hline $\begin{array}{l}\text { TOTAL AA }(\mathrm{g} / 100 \mathrm{~g} \\
\text { protein) }\end{array}$ & $\begin{array}{c}81.5 \\
6\end{array}$ & $\begin{array}{c}67.5 \\
4\end{array}$ & $\begin{array}{c}62.6 \\
8\end{array}$ & $\begin{array}{c}59.8 \\
3\end{array}$ & $\begin{array}{c}58.0 \\
1\end{array}$ & \\
\hline
\end{tabular}

Table 2 shows the total amino acid (TAA), total antioxidant amino acid grouping (TAntAA) and ratios in different germination period of the melinjo seeds. The amount of amino acid composition in germinated melinjo seeds was presented as TAA. The different compositions of amino acids in the germinated melinjo seeds (0-21 days) reflected the different amounts of TAA. The ungerminated period (0 days) contain more TAA than did either (3-21 days), in a range of 14.02-23.55 $\mathrm{g} / 100 \mathrm{~g}$ protein. The amount of TAA in the samples was several dominated by the composition of Lys, Arg and Tyr are similar to the antioxidant amino acid group reported by Xu et al. (2017). The amount of those antioxidant amino acids is presented as TAntAA. Similar to the TAA value, ungerminated seeds contain higher TAntAA than do either, in a range of $2.70-5.19 \mathrm{~g} / 100 \mathrm{~g}$ protein. This is also represented in the ratio of TAntAA/TAA, in which ungerminated ( 0 days has a ratio of 0.265 , a lower value than the either (3-14 days) and the germinated melinjo seeds at $21^{\text {st }}$ days with its high TAntAA/TAA ratio about 0.283 , had more potent antioxidant activity than either. The result of the germination process, melinjo seeds undergo considerable metabolic changes in their storage proteins. Germination is a natural biological process of all superior plants by the seed comes out its latency stage, once the minimal environmental conditions needed for its growth and development, such as humidity, temperature, nutrients (Sangronis et al., 2007).

Table 2 Average amino acid groupings of Gnetum gnemon seed during germination and some ratios

\begin{tabular}{lcccccc}
\hline \multirow{2}{*}{ Groups } & \multicolumn{4}{c}{ Germination Period (day) } & \multicolumn{2}{c}{ CV } \\
\cline { 2 - 5 } & $\mathbf{0}$ & $\mathbf{3}$ & $\mathbf{7}$ & $\mathbf{1 4}$ & $\mathbf{2 1}$ & $\mathbf{( \% )}$ \\
\hline TAA (g/100 g protein) & 81.56 & 67.54 & 62.68 & 59.83 & 58.01 & 0.14 \\
TAntAA (g/100 g protein) & 21.62 & 18.92 & 17.63 & 16.86 & 16.43 & 0.11 \\
TAntAA/TAA (ratio) & 0.265 & 0.280 & 0.281 & 0.282 & 0.283 & 0.03 \\
\hline Legend: TAA=Total Amino Acid; & \multicolumn{4}{l}{ TantAA=Total } & Amino Acid Antioxidant; CV $=$
\end{tabular}

coefficient of variation

\section{Free Radical Scavenging and ACE-I inhibitory Activities}

The results obtained showed that during the germination process the seeds of melinjo with the long period of germination have antioxidant activity in $\mathrm{IC}_{50}$ that tends to decrease in $\mathrm{ABTS}^{2+}$, DPPH, and $\mathrm{O}_{2}{ }^{\bullet}$, but not with $\mathrm{OH}^{\bullet}$ which increases after the $14^{\text {th }}$ days germination period, as listed in Table 3. According to Donkor et al. (2007) that higher antioxidant activity as shown in low $\mathrm{IC}_{50}$ is likely to be a contribution to each phytochemical compound and as a result of metabolic activity. The germination process can make significant changes in the biochemical properties of the seeds due to the activation of enzymatic processes that convert protein storage into bioactive peptides. The protein hydrolyzed is the product of the hydrolysis reaction or the breaking of the peptide bonds in the protein molecule containing a mixture of components of various peptides and free amino acids depending on the degree of hydrolysis. Chen et al. (2017) reported that the degree hydrolysis of protein storage high related with increased of antioxidant capacity on the germination seed and they have observed antioxidant activity in hydrolyzed proteins (small size peptide) due to the exposure of amino acids, resulting in high free radical scavenging activity, reducing power, inhibition of lipid oxidation and metal chelation capacity. The variety of peptides or free amino acid seed Gnetum gnemon was higher than the rest of the seeds and comparable to germinate, this can be attributed to the differential activity of hydrolases and oxidase during germination and differences in seed matrices control in antioxidant capacity.

Table 3 The $\mathrm{IC}_{50}$ value of Antioxidant and ACE-I Inhibitor Activities ${ }^{\#}$

\begin{tabular}{|c|c|c|c|c|c|}
\hline \multirow{2}{*}{ Antioxidant Activity } & \multicolumn{5}{|c|}{ Germination Period (day) } \\
\hline & $\mathbf{0}$ & 3 & 7 & 14 & 21 \\
\hline DPPH (mg/mL) & $2.63 \pm 1.05^{\mathrm{a}}$ & $2.38 \pm 0.38^{\mathbf{a b}}$ & $1.85 \pm 0.87^{\mathrm{ab}}$ & $1.65 \pm 0.56^{\mathrm{ab}}$ & $1.30 \pm 0.30^{\mathrm{bc}}$ \\
\hline $\mathrm{ABTS}^{2+}(\mathrm{mg} / \mathrm{mL})$ & $0.62 \pm 0.12^{\mathrm{a}}$ & $0.32 \pm 0.15^{\mathrm{ab}}$ & $0.19 \pm 0.06^{\mathrm{ab}}$ & $0.013 \pm 0.002^{\mathrm{ab}}$ & $0.006 \pm 0.001^{\mathrm{bc}}$ \\
\hline $\mathrm{O}_{2} \cdot(\mathrm{mg} / \mathrm{mL})$ & $9.12 \pm 0.12^{\mathrm{a}}$ & $3.17 \pm 0.17^{\mathbf{b}}$ & $2.17 \pm 0.10^{\mathbf{b c}}$ & $2.77 \pm 0.23^{\mathrm{cd}}$ & $1.32 \pm 0.33^{\mathrm{d}}$ \\
\hline $\mathrm{OH}^{\bullet}(\mathrm{mg} / \mathrm{mL})$ & $1.91 \pm 0.13^{\mathrm{d}}$ & $1.30 \pm 0.14^{\mathbf{b c}}$ & $1.05 \pm 0.19^{\mathbf{a b}}$ & $0.73 \pm 0.14^{\mathrm{a}}$ & $1.58 \pm 0.13^{\mathrm{c}}$ \\
\hline ACE-I $(\mu \mathrm{g} / \mathrm{mL})$ & $13.23 \pm 0.92^{\mathrm{d}}$ & $9.65 \pm 0.57^{\mathrm{cd}}$ & $8.69 \pm 0.31^{\mathrm{c}}$ & $7.02 \pm 0.42^{\mathrm{b}}$ & $1.14 \pm 0.55^{\mathrm{a}}$ \\
\hline
\end{tabular}

Legend: "The values are means of followed by standard deviation and Duncan's test at $\mathrm{p}<0.05$, where the same letter in a column is not significantly different.

Angiotensin-I converting enzyme assay was performed to evaluate ACE-I inhibitory activity by bioactive proteins produced during the germination process (Magana et al., 2007). The results obtained for the inhibition of ACE-I $\left(\mathrm{IC}_{50}\right)$ at the start of germination were $13.23 \mu \mathrm{g} / \mathrm{mL}$ at the beginning of germination and improved to $21^{\text {st }}$ days by $1.14 \mu \mathrm{g} / \mathrm{mL}$. This suggests that with decreasing $\mathrm{IC}_{50}$ ACE-Inhibitors, there is an increase in the formation of bioactive proteins during the germination process and reaches an optimal value on the $21^{\text {st }}$ days of the germination process. This suggests that relatively fewer specific peptides are produced during the germination process and undergo further cleavage into smaller peptides and more bioactive peptides during the $21^{\text {st }}$ days germination process. Further protein during the longer germination process results in smaller peptides and fewer bioactive peptides. Gnetum gnemon germination process may change the pattern of proteolysis which then form and deactivate proteins with anti-ACE-I activity (Meisel, 1997).

\section{CONCLUSION}

During the process of germination melinjo seed (Gnetum gnemon) a decrease in the value of amino acid due to a process of protein storage hydrolysis which resulted in small-sized peptides with strongly inhibit of the ACE-I and free radical scavenging activities. The results indicated that germination time has positively affected on free radical scavenging activities and ACE-I inhibitory activity.

Acknowledgments: The authors are grateful to the Ministry of Research, Technology, and Higher Education of the Republic of Indonesia.

\section{REFERENCES}

Adler-Nissen, J. (1979). Determination of the degree of hydrolysis of food protein hydrolysates by trinitrobenzenesulfonic acid. J. Agric. Food Chem., 27(6), 1256-1262. https://doi.org/10.1021/jf60226a042

Bhat, R., \& Yahya, N. (2014). Evaluating belinjau (Gnetum gnemon L.) seed flour quality as a base for development of novel food products and food formulations. Food Chemistry, $\quad 156, \quad 42-49$ https://doi.org/10.1016/j.foodchem.2014.01.063

Bonjoch N. P., \& Tamayo, P.R. (2001). Protein Content Quantification by Bradford Method. In: Reigosa Roger M.J. (eds) Handbook of Plant Ecophysiology Techniques. Springer, Dordrecht. https://doi.org/10.1007/0-306$\underline{48057-3 \quad 19}$ 
Chen, Z., Wang, P., Weng, Y., Ma, Y., Gu, Z., \& Yang, R. (2017). Comparison of phenolic profiles, antioxidant capacity and relevant enzyme activity of different Chinese wheat varieties during germination. Food Biosci, 20, 159-167. http://doi.org/10.1016/j.fbio.2017.10.004

Donkor, O.N., Stojanovska, L., Ginn, P., Ashton , J., \& Vasiljevic, T. (2012). Germinated grains-sources of bioactive compounds. Food Chem., 35, 950-959. http://doi.org/10.1016/j.foodchem.2012.05.058

Duangmal, K., \& Sangsukiam, T. (2015). Effect of germination period on changes in mungbean and azuki bean protein and amino acid profiles. Acto Horticulturae, 1088, 563-568. https://doi.org/10.17660/actahortic.2015.1088.103 Fernandez-Orozco, R., Frias, J., Zielinski, H., Munoz, M., Piskula, M,K, Kozlowska, H., \& Vidal-Valverde, C. (2009). Evaluation of bioprocesses to improve the antioxidant properties of chickchickpeas. Food Res. Technol., 42, 885-92. https://doi.org/10.1016/j.lwt.2008.10.013

Gálvez, M., Martín-Cordero, C., Houghton, P.J., \& Ayuso, M.J. (2005). Antioxidant activity of methanol extracts obtained from Plantago species. J Agric Food Chem., 53(6), 1927-1933. https://doi.org/10.1021/jf048076s

Halliwell, B., \& Gutteridge, J.M.C. (1985). Free Radicals in Biology and Medicine. Journal of Free Radicals in Biology \& Medicine. 1(4), 331-332. https://doi.org/10.1016/0748-5514(85)90140-0

Halliwell, B., Gutteridge, J.M., \& Aruoma, O.I. (1987). The deoxyribose method: a simple "test-tube" assay for determination of rate constants for reactions of hydroxyl radicals. Analytical Biochemistry. 165(1), 215-219. https://doi.org/10.1016/0003-2697(87)90222-3

Kiran, C.R., Rao, D.B., Sirisha, N., \& Rao, T.R. (2012). Impact of germination on biochemical and antioxidant enzymes of ceiba pentandra (kapok) seeds. American Journal of Plant Sciences, 3, 1187-1192. http://dx.doi.org/10.4236/ajps.2012.39144

Laemmli, U.K. (1970). Cleavage of structural proteins during the assembly of the head of bacteriophage T4. Nature, 227(5259), 680-685. https://doi.org/10.1038/227680a0

Li, G. H., Le, G. W., Liu, H., \& Shi, Y. H. (2005). Mung-bean protein hydrolysates obtained with alcalase exhibit angiotensin I-converting enzyme inhibitory activity. Food Science \& Technology International, 11(4), 281-287. http://dx.doi.org/10.1177/1082013205056781

Magaña, M.D., Segura-Campos, M., Gloria Dávila-Ortiz, G., David BetancurAncona, D., \& Chel-Guerrero, L. (2015). ACE-I inhibitory properties of hydrolysates from germinated and ungerminated Phaseolus lunatus proteins. Food Sci. Technol (Campinas), 35(1), 167-174. http://dx.doi.org/10.1590/1678457X.6551

Mamilla, R.K., \& Mishra, V.K. (2017). Effect of germination on antioxidant and ACE inhibitory activities of legumes. LWT-Food Science and Technology, 75, 51-58. https://doi.org/10.1016/j.1wt.2016.08.036

Meisel, H. (1997). Biochemical properties of regulatory peptides derived from milk proteins. Peptide Science, 43(2), 119-128. https://doi.org/10.1002/(SICI)1097-0282(1997)43:2<119::AID-BIP4>3.0.CO;2$\underline{Y}$

Ramakrishna, V., \& Ramakrishna R.P. (2006). Storage protein degradation in germinating Indian bean (Dolichos lablab L. var. lignosus) seeds. Seed Science and Technology, 34(1), 161-168. https://doi.org/10.15258/sst.2006.34.1.17

Re, R., Pellegrini, N., Proteggente, A., Pannala, A., Yang, M., \& Rice-Evans, C. (1999). Antioxidant activity applying an improved ABTS radical cation decolorization assay. Free Radic Biol Med., 26(9-10), 1231-1237. https://doi.org/10.1016/s0891-5849(98)00315-3

Sangronis, E., Rodriguez, M., Cava, R., \& Torres, A. (2006). Protein quality of germinated Phaseolus vulgaris. European Food Research and Technology, 222, 144-148. https://doi.org/10.1007/s00217-005-0137-4

Sangronis, E., \& Machado, C.J. (2007). Influence of germination on the nutritional quality of Phaseolus vulgaris and Cajanus Cajan. Food Science and Technology, 40(1), 116-120. http://dx.doi.org/10.1016/j.lwt.2005.08.003

Sefatie, R.S., Fatoumata, T., Eric, K., Yong, H.S., \& Guo-Wei, L. (2013). In vitro antioxidant activities of protein hydrolysate from germinated black soybean (Glycine $\max \quad$ L.). Adv. J. Food Sci. Technol., 5(4), 453-459. https://doi.org/10.19026/ajfst.5.3290

Siswoyo, T. A., Eka, M., Lee, K. O., \& Hosokawa, K. (2011). Isolation and characterization of antioxidant protein fractions from melinjo (Gnetum gnemon) seed. Agricultural and Food Chemistry, 59 (10), 5648-5656. https://doi.org/10.1021/jf2000647

Tang, X., He, Z., Day, Y., Xiong, Y.L., Xie, M., \& Chen, J. (2010). Peptide fractionation and free radical scavenging activity of zein hydrolysate. J. Agric. Food Chem., 58, 587-593. https://doi.org/10.1021/jf9028656

Xu, N., Guanqun, C., \& Hui, L. (2017). Antioxidative categorization of twenty amino acids based on experimental evaluation. Molecules, 22 (12), 2-8 https://doi.org/10.3390/molecules22122066 